\title{
Agrosharing as strategic vector of Education, Science and Business for sustainable development
}

\author{
Mykhailo Broshkov ${ }^{1}$, and Darya Bulysheva ${ }^{1 *}$ \\ ${ }^{1}$ Odesa State Agrarian University, 13 Panteleimonivska str., 65012 Odesa, Ukraine
}

\begin{abstract}
The study substantiates necessity for joint development of scientific structures, educational system and business sector to ensure their sustainability. The aim of the article is to define preconditions, challenges and advantages for joint development of educational, scientific and business areas in agrosharing system as general consumption of material goods, natural resources and intellectual property in agricultural sector. Forms and problems of cooperation of this system's main constituents are given. The study determines preconditions that make impossible segmental sustainable development of education, science and business. They lie in lack of material resources, possibilities for transferring technologies into business, employees' motivation of science and educational area and business structures' awareness of possibilities to leverage manufacturing processes. It is obvious that agrarian sector requires special attention toward well-coordinated work of the system, which includes expensive constantly updated material and technical base, narrow focus of each individual business, necessity for practical circular monitoring research and constantly updated IT platforms for planning and anticipating agrarian businesses. To solve this problem, we have suggested agrosharing as a model of joint consumption of goods, natural resources, material and technical base and intellectual property in interactive system of education, business and science in agrarian sector.
\end{abstract}

\section{Introduction}

In the context of today's intensive development in all spheres of human life considering rapid world digitalization, joint cooperation of science, education and business are indispensable condition for ensuring their sustainable development. The research of international companies' network, providing consulting and audit service PricewaterhouseCoopers International Limited 2020 [1], has shown that the problem for many companies is to find qualified employees, three quarters of all respondents highlight low new employees' qualification and difficulty in finding professionals.

In the view of Harald Kayser - Senior Partner and Chairman of PwC Europe SE, education is a key element of social and economic prosperity [2]. In the context of agrarian

\footnotetext{
* Corresponding author: bu.dasha.bu@gmail.com
} 
education, these two areas are expanded with ecological one considering necessity to preserve environment and rational land usage as basic agricultural object.

Strong educational system interconnected with fundamental science and business investments might provide young specialists with skills, necessary for business and economy growth. $21^{\text {st }}$ century clearly defined demands to ensure above mentioned subjects interconnection. Classical educational system transformation in the context of COVID-19 pandemic should be carried out without negative consequences for education efficiency with future possibility to return to "face to face" model. Distance learning has a number of benefits - ability to acquire knowledge without leaving home; environmental friendliness, considering reduction in energy consumption and carbon dioxide emissions; profitability. But along with this, world has faced problems of distance learning - difficulties in adapting to online format for both teachers and students; technical difficulties to access high-quality Internet and compatibility of computer equipment with assigned tasks; lack of communication and, as a result, reduced self-motivation for learning; necessity of full and rapid transformation of time management approach and real-time feedback.

When education suddenly and unexpectedly went online, inequality in access to digital learning became obvious. Many students do not have resources to access digital learning. Educational system requires significant investment in infrastructure and goal-oriented policy in the context of necessity to meet 2030 Sustainable Development Agenda under goal 4 "Ensure inclusive and equitable quality education and promote lifelong learning opportunities for all". Especially it refers to targets 4.3, 4.4. and 4.7. that are aimed on ensuring equal access to affordable and quality technical, vocational and tertiary education, including university; increasing the number of youth and adults who have relevant skills, including technical and vocational skills; acquiring the knowledge and skills needed to promote sustainable development. [3]. But still scientists prove that one of the main gaps in institutional support for inclusive governance is limited access to economically viable funds that meet the real needs of the population in terms of education [4].

Educational system does not keep pace with changing demand for professional skills, development of material and technical base at enterprises, formation of sustainable development of applied and fundamental science. Taking into account pace of industrial automation and world digitalization, there is a growing demand for human skills that cannot be replaced by machines (empathy, social-emotional intelligence and creative abilities) or lie "at the confluence" of several directions.

As early as in 2018, World Economic Forum drew attention to the fact that in 4 years [5]. at least 54\% of all employees in enterprises will have to improve their qualifications in reliance to organizations demands. Corresponding research indicates necessity to solve the problem of new technologies influence on labor markets with the help of educational policy modernization.

On the part of enterprises, the most important question lies in providing enterprise with highly qualified employees having potential for sustainable development, because traditional skills are dating rapidly. This includes necessity to extend learning period beyond the "youth". The studies [2] have shown, that 53\% of respondents believe that automation will significantly change their work within a decade and $77 \%$ of respondents want to acquire new professional skills that are in demand in labor market or completely retrain in order to improve recruitment opportunities. Besides, we have observed irrational usage of material and technical base at enterprises (for example, at agrarian enterprises simple expensive machinery for farming operations), lack of consulting support and monitoring of business development and efficiency at all stages; spontaneous support of technological processes without considering activities anticipation and planning, which might only be ensured by scientific component. 
Problems of scientific area include lack of real possibility to implement developments into business due to limited resources (for example, in agrarian sector - land plots, agricultural machinery); absence of demand for fundamental scientific developments without their implementation and assessment in real conditions of market economy; financial and organizational-economic weakness, scientific staff "aging"; social virtualization and escape from reality; decline of scientific activity image. Science is facing problems of constant demand to implement innovative developments and make their assessment, taking into account limited time, material and technical base, human resources. Business needs to solve this problem as soon as possible, wherefore scientific structure needs time to make suggestions, as well as their assessment to obtain reliable results. Specific problem for science is poorly developed mechanisms of patent protection, incubation and commercialization of scientific and technical developments. Scientific technologies, new equipment or products often do not become commercial products. Scientists do not have opportunities to commercialize their suggestions, and, as a result, scientific institutions sometimes cannot bring their scientific and technical development to implementation level. Mechanisms of scientific hubs, business incubators and technology parks performance are not outlined in legislative and commercial format. Distinctive problem for all areas is weak real sector of economy, which does not finance innovative developments, improving education quality and enterprises development. The aim of the article is to define preconditions, challenges and advantages for joint development of educational, scientific and business areas in agrosharing system as general consumption of material goods, natural resources and intellectual property in agricultural sector.

\section{Methods}

In this study, historical method has been used to analyze origin and development of sharing economy, statistical method has been used for analyzing and synthesizing information about necessity of education, science and business according to international indicators by working with digital information, abstract-logical method has been used for promoting and arguing hypothesis about necessity for joint development of higher agricultural education, science and business in agrosharing system.

\section{Results and discussion}

Agrosharing authors understand as collaborative consumption of goods, natural resources, material and technical base and intellectual property in interactive system between education, business and science in agricultural sector. Sharing economy or collaborative economy was studied by such scientists as R. Botsman [6], H. Heinrichs [7], R. Rogers, B. Walsh, T. Slee [8], T. Teubner [9] and others. Idea of "sharing" was suggested by designers from San Francisco in 2008, and later the largest sharing platform Airbnb.com was formed. As a general consumption model it was formed [8] under the slogan "What is mine - yours" in 2010. The main idea is that consumer only needs temporary access to service, goods, resource, but not the right to possess them. Consumers' active using new technological opportunities based on widescale world digitalization revealed qualitative changes in consumers behavior and their preferences in favor of new sharing technologies instead of possessing. H. Heinrichs' research [7] has shown new approach to sharing economy development as a potential new pathway to sustainable development and environmental protection. Multiple using, for example, a car (or, in our case, agricultural machinery) might change manufacturing volumes in relevant industry and reduce impacts on nature. Timm Teubner [9] emphasizes that sharing economy can be viewed from two sides - as a mechanism for enhancing environmental factor's role ensuring sustainable growth; as implementation of "flea 
markets" principle and microentrepreneurship, transferred to the Internet and based on mobile applications [9].

Sharing economy is a new model where, with the help of technology and online platforms, participants can exchange assets and share them. Based on this model, many types of successful entrepreneurial activities have appeared: short-term shared mobility (car sharing), in education - Wikipedia and MOOCs (Massive Open Online Courses), search for a car with a driver (for example, Uber and Lyft), co-financing of projects (crowdfunding), timeshare (coworking), short-term rental of premises for business trips and travelling (Airbnb), etc.

Sharing economy volume will reach $\$ 335$ billion by 2025 , according to $\mathrm{PwC}$, therefore, over the decade of its existence, sharing economy has ceased to be a financial theory and is becoming an increasingly powerful global force.

European consulting company Juniper Research predicts that market value of sharing economy will reach over $\$ 40$ billion by 2022, and Alex Stephanie (founder of the world's first online crowdfunding platform) for employment of homeless, estimated sharing economy cost at about 26 billion dollars a year in his book [10].

According to international first rating for sharing economy Timbro Sharing Economy Index, Ukraine has Index 0,6 (Table 1). That means that our country has organizations which understand effectiveness of this model, but it needs support for development. For making this index data for 286 services in 213 countries was collected. Scientists have considered 4,651 service candidates worldwide, 286 of which were classified as sharing economy services [11].

One of the main peculiarities of this sharing is active Internet usage. To simplify and accelerate sharing, specialized Internet platforms or online ad services are being created that help establish direct, without intermediaries, connections between consumers and suppliers of goods and services.

General preconditions that make impossible segmental sustainable development of education, science and business are:

- lack of material resources to ensure digitalization of educational and scientific activity considering modern demands alongside business's inability to create a model for successful implementation of digitalization into manufacturing process;

- possibilities for transferring technologies into business, employees' motivation of science and educational area and business structures awareness of possibilities to leverage manufacturing processes;

- lack of enterprise's interest in transferring technologies, which leads to interest decrease in scientific activity and absence of new technologies developed under the conditions of certain business;

- low motivation of higher educational establishments to improve applicants' training quality which results in decreasing youth's interest in science; low employees' qualification at enterprises, scientific staff "aging";

- lack of business structures administration's awareness of possibilities to leverage manufacturing processes considering innovative developments (assessed at certain enterprise) and effective staffing in cooperation with educational establishments.

The problems studied are especially acute in agricultural sector, as it includes expensive constantly updated material and technical base, narrow focus of each individual production, necessity for practical circular monitoring research and constantly updated IT platforms for planning and anticipating agrarian businesses.

It is possible to solve above-mentioned educational problems under the condition of interaction between higher education system and enterprise from the first years of providing classical education, considering material and technical base and particular enterprise's demand. Besides, education system requires close connection with fundamental science as 
it aims to create theoretical concepts and models. Higher education system, in this case, can provide practical side of assessing corresponding results. Previous researches in the area of defining and implementing key performance indicators of higher education institutions was also maximally focused on a commercial basis and has approved itself as an effective tool for solving managerial problems and motivating staff at all levels of management [12].

Table 1. Sharing economy rating.

\begin{tabular}{|c|c|c|}
\hline № & Group of countries & $\begin{array}{c}\text { Interval of } \\
\text { index }\end{array}$ \\
\hline 1. & Iceland & $90-100$ \\
\hline 2. & - & $80-90$ \\
\hline 3. & - & $70-80$ \\
\hline 4. & Turks and Caicos Islands & $60-70$ \\
\hline 5. & Malta, Montenegro, New Zealand, Croatia & $50-60$ \\
\hline 6. & Faroe Islands, Denmark, Aruba, Ireland, United States Virgin Islands & $40-50$ \\
\hline 7. & Bermuda, Curaçao, Monaco & $30-40$ \\
\hline 8. & $\begin{array}{l}\text { Barbados, Norway, Australia, Portugal, France, Dominica, Seychelles, } \\
\text { Andorra, Spain, Greece, Cuba, Italy, United Kingdom of Great Britain and } \\
\text { Northern Ireland, Georgia, Cayman Islands }\end{array}$ & $20-30$ \\
\hline 9. & $\begin{array}{l}\text { Bahamas, Cyprus, Saint Lucia, Canada, Isle of Man, Switzerland, } \\
\text { Grenada, French Polynesia, Netherlands, Estonia, Palau, New Caledonia, } \\
\text { Sweden, Antigua and Barbuda, Israel, Finland, Greenland, Uruguay, } \\
\text { Mauritius, Belize }\end{array}$ & $10-20$ \\
\hline 10. & $\begin{array}{l}\text { Gibraltar, Saint Vincent and the Grenadines, United States of America, } \\
\text { Belgium, Northern Mariana Islands, Maldives, Liechtenstein, Latvia, } \\
\text { Jamaica, San Marino, Hungary, Cabo Verde, Bulgaria, Bosnia and } \\
\text { Herzegovina, Singapore, Saint Kitts and Nevis, The former Yugoslav } \\
\text { Republic of Macedonia, South Africa, Malaysia, Guam, Serbia, Vanuatu, } \\
\text { Fiji, Brazil, China, Hong Kong Special Administrative Region, Armenia, } \\
\text { Germany, Sri Lanka, Albania, Tonga, Dominican Republic, Mexico, } \\
\text { Trinidad and Tobago, Argentina, United Arab Emirates, Morocco, } \\
\text { Suriname, Romania, Thailand, Republic of Korea, Japan, Poland, } \\
\text { Nicaragua, Turkey, Ecuador, Samoa, Tunisia, Mongolia, Brunei } \\
\text { Darussalam, Saudi Arabia, China, Macao Special Administrative Region, } \\
\text { Lebanon, Philippines, Sao Tome and Principe, Russian Federation, } \\
\text { American Samoa, Kenya, Lithuania, Guatemala, Puerto Rico, Republic of } \\
\text { Moldova, Botswana }\end{array}$ & $1-10$ \\
\hline 11. & $\begin{array}{l}\text { Cambodia, Austria, Vietnam, Panama, Jordan, Tuvalu, Kazakhstan, } \\
\text { Senegal, Costa Rica, Somalia, Nauru, Azerbaijan, El Salvador, Kyrgyzstan, } \\
\text { Bhutan, Ukraine, United Republic of Tanzania, Egypt, Czechia, Gambia, } \\
\text { Indonesia, Gabon }\end{array}$ & $0,5-1$ \\
\hline 12. & $\begin{array}{l}\text { Guyana, Qatar, Oman, Nepal, Slovenia, Honduras, Paraguay, Peru, } \\
\text { Swaziland, Colombia, Marshall Islands, Bahrain, Libya, Iran, China, South } \\
\text { Sudan, Bolivia, Zimbabwe, Ethiopia, British Virgin Islands, Zambia, } \\
\text { Ghana, Micronesia, Uganda, Algeria, Lao People's Democratic Republic, } \\
\text { Djibouti, Yemen, Belarus, Mauritania, Rwanda, Haiti, Angola, Solomon } \\
\text { Islands, Kiribati, Côte d'Ivoire, Madagascar, India, Togo, Timor-Leste, } \\
\text { Lesotho, Slovakia, Mozambique, Cameroon, Benin, Turkmenistan, Mali, } \\
\text { Venezuela, Sudan, Kuwait, Tajikistan, Congo, Burkina Faso, Iraq, Malawi, } \\
\text { Syrian Arab Republic, Sierra Leone, Myanmar, Comoros, Liberia, Chad, } \\
\text { Papua New Guinea, Democratic Republic of the Congo, Niger, Nigeria, } \\
\text { Guinea-Bissau, Uzbekistan, Guinea, Central African Republic, Pakistan, } \\
\text { Afghanistan, Bangladesh, Equatorial Guinea, Burundi, Democratic } \\
\text { People's Republic of Korea, Saint Martin (French Part), Luxembourg }\end{array}$ & $0-0,5$ \\
\hline
\end{tabular}

Source: formed according to [11] 
In the context of world digitalization and necessity for sustainable development of social, economic and environmental components, implementation of lifelong education, dual education in cooperation with education, and consulting centers with parallel provision of technology transfer in cooperation with science, becomes essential mechanism for enterprises. Scientific area in cooperation with educational and business sector, will receive young scientists, entities for laboratory research and base for implementation of scientific activities into manufacturing.

Considering above-mentioned, we suggest sharing scientific potential, services for quality education, material and technical base and resources of scientific institutions, educational structures and enterprises of agrarian complex - agrosharing (Fig. 1) based on monitoring GIS platform, which will include:

1. Spatial component:

- cartographic framework as a base layer, which will be constantly updated using UAVs and satellite observations, taking into account constant specific changes in agricultural sector;

- territorial location layers of higher education institutions, scientific organizations, laboratories, enterprises of agricultural sector.

2. Attributive component:

- database of agrarian, natural resource, technical and polytechnic institutions of higher education considering agrarian sector potential;

- database of scientific institutions of corresponding focus area;

- database of laboratories ranging in services provided;

- database with results of monitoring agricultural land, considering agricultural enterprises' demands;

- list of agricultural enterprises participating in agrosharing model.

We consider science, education and business as interrelated and interdependent elements of innovative agrosharing framework. Science is a supply source and environment for business and education, business is a source of innovation and main research and development investor, education is a source of staff training for science and business. It is impossible to train highly qualified specialists without students' active industrial work placement at innovative enterprises. Science cannot develop effectively with poor education. And it is the same vice versa. Below we show the main possible forms and problems of agrosharing key elements' interaction between themselves.

1.Education and science interaction is regulated by title establishing documents of respective institutions, which include constant interaction of applied and fundamental science in these organizations. Implementing Bologna system to higher education replaces fundamental students' training with acquiring branch competences oriented on existing labour market without anticipating this area changes. Restoring close ties of interaction between science and education does not contain fundamental problems, since scientific and educational sector of education and scientific institutions carry out parallel work, sometimes facing same problems.

2.Education and business interaction is absolutely impossible to ensure without students' access to modern technologies and equipment. In this case, dual education form has become innovative solution to corresponding problem. It is a way to get education, which includes simultaneous education at the institute and at working place to acquire certain qualification. Specialists take theoretical training on the basis of higher education institution, while practical part is taken at the enterprise. It means that both an educational institution and an enterprise are involved in young specialists' training. Such system essence lies in close interaction between enterprise and educational institutions on the basis of social partnership, where both parties are equal partners who develop and coordinate educational process, monitor its results. 


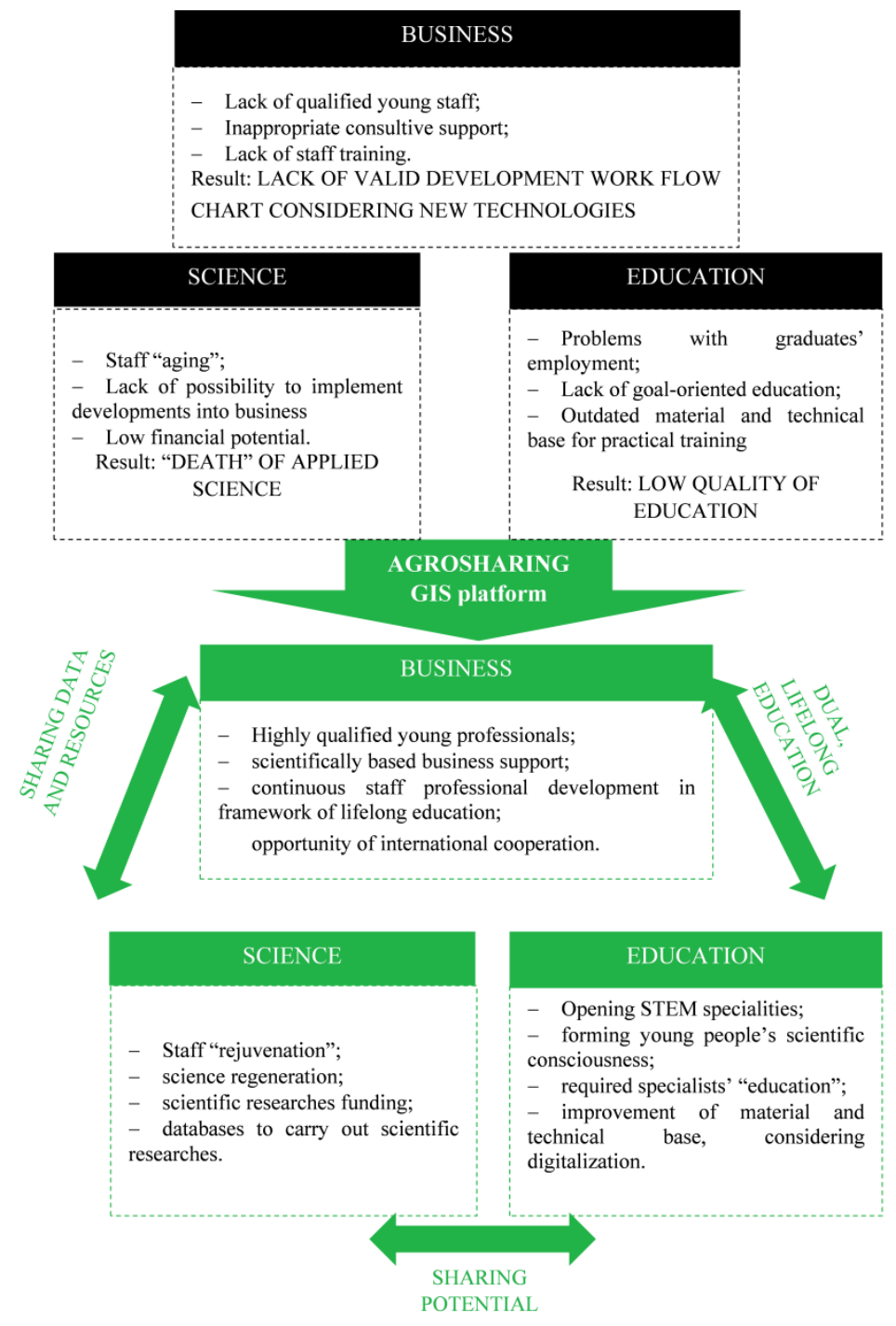

Fig 1. Logframe of agrosharing model benefits.

However, enterprise defines number of specialists in the specialty they require and participate in planning their curriculum. Enterprise can have various forms of participation in specialists' training - paying for training; purchasing equipment; paying monetary rewards for using students' labour, etc.

3. In the process of improving employees' qualifications, these above-mentioned entities should interact within framework of lifelong education as an approach that implies constant acquiring new skills and knowledge, and, as a result, forming personal education system. According to analytical data, there are 4 key factors that require advanced training:

- increasing job automation;

- decreasing talent availability;

- decreasing mobility of skilled labour;

- ageing talent [13]. 
In this case, educational institutions might become the basis for right choice of advanced training course based on stakeholders' demands. Companies must consider advanced training and workforce investment as essential principle of their business and undertake a commitment to meet deadlines. Educational institutions must rethink their approach to advanced training and retraining and use lifelong education to ensure everyone's opportunity to be competitive in labor market.

4. Science and business interaction might be carried out in various contractual forms. Any scientific and research structure should be primarily focused on developments commercialization. Effective results might be shown both by higher education institutions in science and scientific structures in the context of business financing. This might be explained by the fact that scientists do not have proper personalized responsibility for spending budget funds, quality and deadline for completion of funded work. Principal output from completed budgetary funded work of scientific structures is chapters' implementation of candidate and doctoral dissertations, as well as preliminary studies for scientific publications as main activity indicator. In the context of private financing, business becomes both a customer and a consumer of scientific developments. They form not only topics for innovative developments, but also set deadlines and desired results.

Contradiction hinders innovative business interaction with education and science. On the one hand, business is interested in cooperation because it selects future employees among students. On the other hand, business restricts access of unauthorized people to manufacture in order to maintain competitive advantages and trade secrets. Therefore, educational structures do not actively intensify this activity.

\section{Conclusions}

Social aspect of trust in such a model of process participants remains controversial issue, as well as technological aspects of creating agrosharing platform, considering necessity to process a large amount of constantly updated information, require further research.

Study results have given reasons to substantiate multidirectionality in activity of scientific structures, education system and business nowadays. We consider transformation of their activity to be relevant, taking into account world digitalization and implementation of IT and Artificial Intelligence in all spheres of human life.

As a result of above-mentioned, agrosharing is considered as optimal model in agrarian sector, under the conditions of sharing natural resources, material and technical base and intellectual property with the help of GIS platform. We suggest considering issue of allocating 1-3\% of stakeholders' income from agrobusiness area to develop agrosharing GIS platform in exchange for state tax remissions.

Undeniable benefits of agrosharing implementation are improving education quality and, as a result, young staff qualifications; increasing of students' interest in research; scientific resources "rejuvenation"; synergy of scientific, educational and business resources; expanding opportunities for integration into international space; future specialists' social adaptation; increasing material and technical opportunities of educational and scientific institutions; creating educational laboratories to simulate technological processes and, as a result, increasing level of students' practical training; constant entry of sought-after specialists; obtaining work flow chart for optimizing enterprises' activities and, as a result, increasing enterprises' competitiveness; increasing demand for technological innovation; ensuring monitoring of resources' quality and manufactured products; anticipating and preventing risks; etc. Above-mentioned components result in sustainable development of territory's agrarian complex. 


\section{References}

1. PwC. (2018). Navigating the rising tide of uncertainty [Brochure]. https://www.pwc.com/ee/et/publications/pub/pwc-23rd-global-ceo-survey.pdf

2. Kayser, H. (2020). A responsive, accessible education system is the engine of social and economic progress [White paper]. PwC. https://www.pwc.com/gx/en/issues/trust/commonpurpose/a-responsive-accessible-education-system.html

3. United Nations Statistical Commission. (2015). Technical report by the Bureau of the United Nations Statistical Commission (UNSC) on the process of the development of an indicator framework for the goals and targets of the post-2015 development agenda. Bureau of the United Nations Statistical Commission, United Nations.

4. Kostetska, K., Khumarova, N., Umanska, Y., Shmygol, N., \& Koval, V. (2020). Institutional Qualities of Inclusive Environmental Management in Sustainable Economic Development. Management Systems in Production Engineering, 28(1), 15-22. https://doi.org/10.2478/mspe2020-0003

5. Centre for the New Economy and Society (2018). The Future of Jobs Report 2018. Centre for the New Economy and Society, World Economic Forum. http://www3.weforum.org/docs/WEF Future of Jobs 2018.pdf

6. Botsman, R. \& Rogers, R. (2010) What's Mine Is Yours: The Rise of Collaborative Consumption. HarperBusiness.

7. Heinrichs, H. (2013) Sharing economy: A potential new pathway to sustainability. Gaia-ecological Perspectives for Science and Society, 22 (4), 228-231. https://doi.org/10.14512/gaia.22.4.5.

8. Slee, T. (2017). What's Yours Is Mine: Against the Sharing Economy. New York; London: OR Books. http://www.jstor.org/stable/j.ctv62hf03

9. Hawlitschek, F., Teubner, T. \& Weinhardt, C. (2016). Trust in the Sharing Economy. Die Unternehmung - Swiss Journal of Business Research and Practice. 70. 26-44. https://doi.org/10.5771/0042-059X2016-1-26

10. Stephany, A. (2015) The Business of Sharing: Making it in the New Sharing Economy. The Business of Sharing: Making it in the New Sharing Economy. Palgrave Macmillan UK https://doi.org/10.1057/9781137376183

11. Bergh, A., Funcke, A. \& Joakim Wernberg J. (2018) Timbro Sharing Economy Index [Brochure]. Timbro. https://timbro.se/app/uploads/2018/07/tsei-version-17_web.pdf

12. Broshkov, M., Forostian, O., Kichuk, Y., Liapa, M., Horbashevska, M. \& Kakhiani, Y. (2020). Management of key performance indicators by heads of higher education institutions. International Journal of Management (IJM), 11(5), 286-298. https://doi.org/10.34218/IJM.11.5.2020.028

13. World Economic Forum. (2021). Upskilling for Shared Prosperity. WEF \& PwC. https://www.pwc.com/gx/en/issues/upskilling 